\title{
Assessment of Motorcycle Noise Exposure Levels (LAeq, dBA) at Various Noise Standards and Speeds
}

\author{
Anila Ali 1, Roslinah Mohamad Hussain 2, Akehsan Dahlan 2, Ali Asghar ${ }^{1}$ \\ 1 Balochistan University of Information Technology, Engineering and Management Sciences, Quetta, Pakistan. \\ ${ }^{2}$ Faculty of Health Sciences, Universiti Teknologi MARA, Selangor Malaysia. \\ anila.zafar@buitms.edu.pk, roslinah561@uitm.edu.my, akehsan@uitm.edu.my, ali.asghar@buitms.edu.pk: \\ Tel: +92-333-7990666
}

\begin{abstract}
Motorcyclists ( $n=26)$ average noise exposure levels (LAeq) were found substantially different for OSHA-HC ( $85 \mathrm{dBA})$, OSHA-PEL (78 $\mathrm{dBA}$ ) and $\mathrm{ACGIH/NIOSH}(87 \mathrm{dBA})$ noise standards. A significant difference in LAeq, $(p=.027)$ and engine capacity usage $(p=.045)$ was found amongst gender. However, no observable association was found between the LAeq and motorcycle engine capacity $(p=$ $.462)$ and completion of a ride $(p=.695)$. Thus, female riders were inclined to use lower motorcycle capacities, rode at lower speeds which resulted in lower noise exposure levels, in concurrence with longer ride durations. Overall, motorcyclists' noise exposure level functions with the increasing speed $(80 \mathrm{~km} / \mathrm{h}: 88 \mathrm{dBA})$.
\end{abstract}

Keywords: Motorcycle noise; Dosimeter; Speed; Noise standards

eISSN: 2398-4287@ 2020. The Authors. Published for AMER ABRA CE-Bs by e-International Publishing House, Ltd., UK. This is an open access article under the CC BYNC-ND license (http://creativecommons.org/licenses/by-nc-nd/4.0/). Peer-review under responsibility of AMER (Association of Malaysian Environment-Behaviour Researchers), ABRA (Association of Behavioural Researchers on Asians) and CE-Bs (Centre for Environment-Behaviour Studies), Faculty of Architecture, Planning \& Surveying, Universiti Teknologi MARA, Malaysia.

DOI: https://doi.org/10.21834/ebpj.v5i15.2455.

\subsection{Introduction}

In Asian countries, the motorcycle is the dominant mode of transportation with a rapidly growing trend (amongst 19- 29 yrs) in motorization (Loo et al., 2015). The increasing trend in the use of motorcycles not only contributes to road accidents but also to noise pollution because it is the noisiest form of transportation (Harvey et al., 2002). Motorcycles are recognized as a convenient form of transport as it causes less damage to the road surface, lessens traffic congestion, and consumes less fuel than motorcars. Motorcycling carries obvious and some less obvious hazards, where noise exposure and its related health effects are one of the less obvious hazards (Binnington et al., 1993). Quieter machines have been developed by the manufacturers with increasingly faster motorcycles, but aeroacoustics noise stands more important for motorcycling and helmet design (Jordan et al., 2004). Motorcyclists are exposed to noise levels above $90 \mathrm{dBA}$ at $50 \mathrm{~km} / \mathrm{h}$, which increases to $105 \mathrm{dBA}$ with increasing speed $(115 \mathrm{~km} / \mathrm{h})$ (Jordan et al., 2004).

Advanced technology has improved motorcycle performance with quieter machines but the exposure of turbulent airflow around the helmet creates excessive noise termed as wind noise (Lower et al., 1996). As defined by Jordan et al., 2004 "Any large object moving at speed will create turbulent airflow around it, be it a bullet, car or motorcycle; this applies equally to the head (and helmet) of a motorcyclist". Wind creates a unique noise exposure to the motorcyclists influenced by the transmission through the helmet ( $\mathrm{J}$ Kennedy et al., 2014).

Continuous exposure to noise levels above $80 \mathrm{dBA}$ over an extended period can affect the quality of life among young motorcyclists

eISSN: 2398-42870 2020. The Authors. Published for AMER ABRA CE-Bs by e-International Publishing House, Ltd., UK. This is an open access article under the CC BYNC-ND license (http://creativecommons.org/licenses/by-nc-nd/4.0). Peer-review under responsibility of AMER (Association of Malaysian Environment-Behaviour Researchers), ABRA (Association of Behavioural Researchers on Asians) and cE-Bs (Centre for Environment-Behaviour Studies), Faculty of Architecture, Planning \& Surveying, Universiti Teknologi MARA, Malaysia.

DOI: https://doi.org/10.21834/ebpj.v5i15.2455 
such risk for hearing damage (J Kennedy et al., 2014), Brown \& Gordon, 2011 reported that high to moderate noise levels hindered reaction times, impaired attention and reduced perceptual and behavioural response effectiveness. In recent studies on young motorcyclist's (19-25 years), increased physiological stress reaction (Anila Ali, Dom, et al., 2017); (Anila Ali, Hussain, Abdullah, et al., 2018); (Anila Ali, Hussain, Dom, et al., 2018), cognitive decline (Anila Ali \& Hussain, 2018b);(Anila Ali \& Hussain, 2018a), diminished quality of life (Anila Ali, Hussain, et al., 2017) and poor audiometry profile (Anila Ali, Dom, et al., 2018) were reported.

\subsection{Literature Review}

Several studies explored the contributing causes that may impact the generation of motorcycling noise, which varied enormously in study designs and instruments. Table 1 illustrates a descriptive summary of previous studies that were conducted on investigating motorcycle noise exposure levels. Most studies were conducted with limited sample size (Chris Jordan, Oliver Hetherington, Alan Woodside, 2004); (Ross, 1989a); (Jordan et al., 2004); (Carley et al., 2010); (J Kennedy et al., 2013) whilst others used mannequins (J Kennedy et al., 2014); (Carley et al., 2011a); (Carrilho \& Silva, 2012); (García Violini et al., 2016); (Violini et al., 2015); (J. Kennedy et al., 2011); (John Kennedy, Carley, et al., 2011). Study testing sites in previous studies varied from on-roads (motorway and towns) noise assessment to wind tunnel facilities. These studies investigated several variables including types of helmets (close face, open face, full face), weather conditions (wet or dry), traveling speed, windshield (angle, location, and position), visor, wind direction, head position, riding position (bent or erect), under helmet surface boundary cavity at the chin and variations in the helmet (with or without neck seal). External factors were summarized by Carley et al., 2011a as wind speed and direction, engine capacity, windscreen alignment, helmet type, and riding position or posture. Several different types of instruments were used in motorcycle noise assessment in these studies which included: Sound Level Meter (SLM) (Carley et al., 2010); (Jordan et al., 2004); (Violini et al., 2015); (García Violini et al., 2016), Digital Recording Tape (DAT) and tape analyzer (Harvey et al., 2002); (Ross, 1989b); (Chris Jordan, Oliver Hetherington, Alan Woodside, 2004); (John Kennedy, Carley, et al., 2011); (Van Moorhem WK, Shepherd KP, Magleby TD, 1981); (Brown \& Gordon, 2011), multiple memory noise logging dosimeters (Binnington et al., 1993), and 16 Channel Data Acquisition (DAQ) system (Carley et al., 2011b); (J Kennedy et al., 2014); (John Kennedy, Holt, et al., 2011); (J Kennedy et al., 2013). All studies emphasized the effects of motorcycling on occupational motorcyclists.

Discrepancies exist in the previously reported studies on motorcycling noise exposure levels with its associated variables. Realtime assessment of motorcycle noise levels at various speeds would be unsafe and such studies are scarce. Noise assessment inside a motorcycle at traveling speeds up to $120 \mathrm{~km} / \mathrm{h}$ is a difficult task to conduct (Harvey et al., 2002). And so, on-road data acquisition is problematic for the rider's safety, alongside with portability of the appropriate instrument. Secondly, non-standardized protocols and methods for measuring engendering motorcycle noise levels under motorcycle helmets (Jordan et al., 2004), and non-standardized permissible noise emission levels for commuter motorcyclists have led to discrepancies in the investigations (A Ali et al., 2018).

Table 1. Summary of studies related to motorcycle noise exposure assessment of motorcycle riders

\begin{tabular}{|c|c|c|c|}
\hline $\begin{array}{c}\text { Author \& Noise measurement } \\
\text { devices }\end{array}$ & Study design & Variables & Results \\
\hline $\begin{array}{ll}\text { Moorhem et al. } 1981 \\
\text { - } & \text { General radio } \\
\text { - } & \text { SLM } \\
\text { - } & \text { Tape recorder } \\
\text { - } & \text { Hotwire anemometer }\end{array}$ & $\begin{array}{l}2 \text { samples } \\
\text { Automobile on } \\
\text { car assessment }\end{array}$ & $\begin{array}{l}\text { - Types of helmets } \\
\bullet \text { Bell star } \\
\text { - Bell super magnum with shield, } \\
\text { visor, sunglasses }\end{array}$ & $\begin{array}{l}\text { - Full face helmet generates high noise levels. } \\
\text { - Conventional helmet with full face shield lower noise. } \\
\text { - Wind noise is a significant contributor to noise at constant } \\
\text { speeds greater }(<10 \mathrm{~m} / \mathrm{s}) \text {. } \\
\text { - Tightly fitted helmets reduce noise. } \\
\text { - Professional riders at higher risk of hearing damage. }\end{array}$ \\
\hline $\begin{array}{l}\text { Ross, 1989b } \\
\text { - } \quad \text { Miniature microphones. } \\
\text { - } \quad \text { Cassette recorder } \\
\text { - } \quad \text { Tape analyzers: } \\
\text { a. integrated sound level } \\
\text { b. frequency spectrum and time } \\
\text { history to identify the main } \\
\text { components of noise. } \\
\text { - } \quad \text { Sound Level Meter }\end{array}$ & $\begin{array}{l}\text { 1 sample } \\
\text { Motorway and } \\
\text { town riding }\end{array}$ & $\begin{array}{l}\text { - Speed } \\
\text { - Type of helmet: Open and full-face } \\
\text { helmet } \\
\text { - Motorway and town }\end{array}$ & $\begin{array}{l}\text { - Town: full-face helmet sound ranged } 63-90 \mathrm{dBA} \text {. } \\
\text { - Motorway: Full-face helmet sound ranged from } 95 \text { at } 30 \mathrm{mph} \text { to } \\
105 \mathrm{dBA} \text { at } 70 \mathrm{mph} \text {. }\end{array}$ \\
\hline $\begin{array}{l}\text { Binnington et al., } 1993 \\
\text { - QUEST: Dosimeter } \\
\text { - } 8 \mathrm{~mm} \text { microphone } \\
\text { - Magnetic tape } \\
\text { - Frequency analyzer }\end{array}$ & $\begin{array}{ll}19 & \text { samples } \\
\text { Road } & \end{array}$ & $\begin{array}{l}\text { - Helmet } \\
\text { - Non-helmet } \\
\text { - Speed }\end{array}$ & $\begin{array}{l}\text { - The acoustic environment was louder for bareheaded riders. } \\
\text { - It is not constant for riders. } \\
\text { - It changes both in character and volume in function of speed. }\end{array}$ \\
\hline $\begin{array}{l}\text { Lower et al., } 1996 \\
\text { - Two motorcycles } \\
\text { - Miniature microphones }\end{array}$ & $\begin{array}{l}\text { Wind-tunnel } \\
\text { Road }\end{array}$ & $\begin{array}{l}\text { - Different types of helmets } \\
\text { - The windshield's height and } \\
\text { angle. }\end{array}$ & $\begin{array}{l}\text { - Windscreen's height and angle are important factors for wind } \\
\text { noise. } \\
\text { - Edge of windscreen highly turbulent. } \\
\text { - Up to } 6 \mathrm{dBA} \text { reductions with sealing around the helmet base. } \\
\text { - } 70-80 \mathrm{dBA}(48 \mathrm{~km} / \mathrm{h}) \text { to } 114-116 \mathrm{dBA}(193 \mathrm{~km} / \mathrm{h}) \text {. }\end{array}$ \\
\hline $\begin{array}{l}\text { Jordan } 2000 \\
\text { - Miniature microphone } \\
\text { - Sound Level Meter (CEL-593) }\end{array}$ & Public road & $\begin{array}{l}\text { - Types of helmets } \\
\text { - Speed } \\
\text { - Motorcycling styles }\end{array}$ & $\begin{array}{l}\text { - Wind noise increases with increasing speed } \\
\text { - The lowest recorded noise was } 83.66 \mathrm{dBA} \text { and the highest } 109.4 \\
\text { dBA. }\end{array}$ \\
\hline $\begin{array}{l}\text { Author \& Noise measurement } \\
\text { devices }\end{array}$ & Study design & - Variables & Results \\
\hline
\end{tabular}




\begin{tabular}{|c|c|c|c|}
\hline $\begin{array}{l}\text { Jordan et al., } 2004 \\
\text { - Miniature Microphone } \\
\text {-DAT }\end{array}$ & On-Road & $\begin{array}{l}\text { - Types of helmets } \\
\text { - Speeds } \\
\text { - Neck seal at the base of the } \\
\text { helmet }\end{array}$ & $\begin{array}{l}\text { - The highest recorded noise was } 110.6 \mathrm{dBA} \text { and the lowest } 76.1 \\
\mathrm{dBA} \text {. } \\
\text { - Full face: } 88.3 \mathrm{dBA} \text { at } 50 \mathrm{~km} / \mathrm{h} \text { upto } 103.6 \mathrm{dBA} \text { at } 120 \mathrm{~km} / \mathrm{h} \text {. } \\
\text { - Open face: } 87.2 \mathrm{dBA} \text { at } 50 \mathrm{~km} / \mathrm{h} \text { up to } 98.5 \mathrm{dBA} \text { at } 120 \mathrm{~km} / \mathrm{h} \text {. } \\
\text { - Visor position was not the dominating source of wind noise. } \\
\text { - Fairing increases noise levels. }\end{array}$ \\
\hline $\begin{array}{l}\text { Carley et al., } 2011 \\
\text { - } \text { GPS measurements. } \\
\text { - Sound Level Meter. } \\
\text { - } \text { Binaural microphones } \\
\text { - } \text { External pressure sensor } \\
\end{array}$ & On-road & $\begin{array}{l}\text { - Windscreen } \\
\text { - Riding position } \\
\text { - Motorcycle types } \\
\text { - Closed face full helmet }\end{array}$ & $\begin{array}{l}\text { - Vortex shielding generates noise flow from motorcycle } \\
\text { windscreen. } \\
\text { - High and moderate speed showed a similar frequency to low } \\
\text { speed. }\end{array}$ \\
\hline $\begin{array}{l}\text { Carley et al., 2011b } \\
\text { - Wind tunnel } \\
\text { - } 1 / 4 \text { inch } 130 \text { D } 20 \text { PCB Piezotronics } \\
\text { microphone. } \\
\text { - Mini-XLR Lavalier microphones \& } \\
\text { USB- DUX } \\
\text { - } 16 \text { Channel DAQ system. } \\
\text { - Stereo digital recorder. } \\
\end{array}$ & $\begin{array}{l}\text { One sample } \\
\text { Experimental } \\
\text { study design: } \\
\text { wind tunnel } \\
\text { tests and on- } \\
\text { track (circuit) }\end{array}$ & $\begin{array}{l}\text { - Head position. } \\
\text { - Wind direction. } \\
\text { - Speeds:40,60,80,100 km/h } \\
\text { - Windshield } \\
\text { - Riders position } \\
\text { - Helmet } \\
\text { - Visor } \\
\text { - Engine noise } \\
\end{array}$ & $\begin{array}{l}\text {-Aerodynamic noise produced by helmet increases with wind flow, } \\
\text { speed, engine type, and windscreen. } \\
\text { - Engine noise range between } 1 \text { and } 3 \mathrm{kHz} \text { at high speeds of } 100 \\
\mathrm{~km} / \mathrm{h} \text {. } \\
\text {-Windscreen contributes to-an increasing divergence of the track. } \\
\text {-Riders riding position also produce different noise levels at-ear. }\end{array}$ \\
\hline $\begin{array}{l}\text { J. Kennedy, Carley, et al., } 2011 \\
\text { - Wind tunnel facility } \\
\text { - Microphone } \\
\text { - Edirol K-09 stereo digital recorder } \\
\text { - Motorcycle and helmet }\end{array}$ & $\begin{array}{l}\text { One sample } \\
\text { On- track } \\
\text { Wind tunnel. }\end{array}$ & $\begin{array}{l}\text { - Windscreen angle } \\
\text { - Windscreen location } \\
\text { - Helmet angle }\end{array}$ & $\begin{array}{l}\text {-The interaction between helmet and windscreen has a difference of } \\
10 \mathrm{~dB} \text {. } \\
\text {-Windscreen tip and helmet angle have a strong impact and an area } \\
\text { for possible noise reduction. }\end{array}$ \\
\hline $\begin{array}{l}\text { J. Kennedy et al., } 2011 \\
\bullet \text { Wind tunnel facility } \\
\end{array}$ & $\begin{array}{l}\text { Wind } \\
\text { test }\end{array}$ & $\begin{array}{l}\text { - Helmet wake. } \\
\text { - Surface boundary cavity under } \\
\text { the helmet at the chin bar. }\end{array}$ & $\begin{array}{l}\text {-Wake and surface boundary have negligence contribution. } \\
\text { - Cavity region around chin main source of noise with helmet angle } \\
\text { and flow speed. }\end{array}$ \\
\hline $\begin{array}{l}\text { Carrilho \& Silva, } 2012 \\
\text { - Mannequin } \\
\text { - Head torso simulator } \\
\text { - Microphones } \\
\text { - Amplifier } \\
\text { - Audio interface }\end{array}$ & $\begin{array}{l}\text { Wind-tunnel } \\
\text { test }\end{array}$ & $\begin{array}{l}\text { - Four models of helmets } \\
\text { - Free flow conditions: with and } \\
\text { without the windscreen }\end{array}$ & $\begin{array}{l}\text {-Noise levels vary with velocity to the power of } 4 \text { with or without } \\
\text { windscreen upstream of the helmet. } \\
\text { - In free-flow conditions, the chin gap presents a dominant source of } \\
\text { the noise. }\end{array}$ \\
\hline $\begin{array}{l}\text { J Kennedy et al., } 2013 \\
-1 / 4 \text { inch PCB microphone } \\
\text { - DAQ system } \\
\text {-Video Cam } \\
\text { - GPS } \\
\end{array}$ & $\begin{array}{l}\text { On-road } \\
\text { Wind tunnel } \\
\text { test }\end{array}$ & $\begin{array}{l}\text { - Speed } \\
\text { - Spectral filtration between } \\
\text { aerodynamic; engine noise } \\
\text { - Windscreen } \\
\text { - Riding position }\end{array}$ & $\begin{array}{l}\text {-Engine noise dominates as a function of speed. } \\
\text { - Fully upright and half-forward riding position results in a change of } \\
10 \mathrm{~dB} \text { at-ear. } \\
\text {-Windscreen produces more aerodynamic effects. }\end{array}$ \\
\hline $\begin{array}{l}\text { J Kennedy et al., } 2014 \\
\text { - Built speaker box } \\
\text { - Pure-tone audiometer } \\
\text { - Sound shelter: IAC } 250 \\
\text { - Amplifier } \\
\text { - Microphones } \\
\text { - } 16 \text { channel National instruments } \\
\text { DAQ System }\end{array}$ & $\begin{array}{l}\text { Field. } \\
\text { Controlled } \\
\text { acoustic } \\
\text { environment }\end{array}$ & $\begin{array}{l}\text { - Helmet } \\
\text { - Free field sound } \\
\text { - Loudness matching } \\
\text { - Filtering effects of helmet } \\
\text { - Closed helmet }\end{array}$ & $\begin{array}{l}\text { - Frequency attenuation below } 500 \mathrm{~Hz} \text { and above } 500 \mathrm{~Hz} \text {. } \\
\text { - Loudness as a strong influencer by the helmet. } \\
\text { - Noise sensitivity increases at high frequencies. }\end{array}$ \\
\hline $\begin{array}{l}\text { Violini et al., } 2015 \\
\text { - Mannequin } \\
\text { - Headphones } \\
\text { - Helmet } \\
\text { - Anemometer } \\
\text {-Anti-vibration platform }\end{array}$ & $\begin{array}{l}\text { On-field } \\
\text { controlled } \\
\text { experiment }\end{array}$ & - Noise attenuation. & $\begin{array}{l}\text { - The robust controller can attenuate noise. } \\
\text { - Time-varying Lpv (linear parameter-varying) can tune noise } \\
\text { attenuation. }\end{array}$ \\
\hline $\begin{array}{l}\text { García Violini et al., } 2016 \\
\text { - SLM } \\
\text { - Anemometer } \\
\text { - Mannequin } \\
\text { - Microphones } \\
\text { - Anti-vibration platform } \\
\end{array}$ & $\begin{array}{l}\text { Freeway } \\
\text { Anechoic } \\
\text { laboratory }\end{array}$ & $\begin{array}{l}\text { - The sound measurement under } \\
\text { the helmet at different points. } \\
\text { - Speed } \\
\text { - Closed helmet } \\
\text { - Attenuation. }\end{array}$ & $\begin{array}{l}\text { - The difference in SPL with and without attenuation } \\
\text { - Lowest } 105.7 \mathrm{dBA} \text { at } 40 \mathrm{~km} / \mathrm{h} \text {, highest } 125.2 \mathrm{dBA} \text { at } 140 \mathrm{~km} / \mathrm{h} \\
\text { without attenuation. } \\
\text { - Lowest } 92.8 \mathrm{dBA} \text { at } 40 \mathrm{~km} / \mathrm{h} \text {, highest } 113.8 \mathrm{dBA} \text { at } 140 \mathrm{~km} / \mathrm{h} \text { with } \\
\text { attenuation. } \\
\text { - Hybrid robust controller attenuation } 20-30 \mathrm{dBA} \text {. }\end{array}$ \\
\hline $\begin{array}{l}\text { Ali et al.,2018 } \\
\text {-Dosimeter }\end{array}$ & $\begin{array}{l}52 \text { riders } \\
\text { Motorway } \\
47 \text { MINS ride }\end{array}$ & $\begin{array}{l}\text { - The sound measurement under } \\
\text { the helmet } \\
\text { - Speeding at maximum } \\
\text { - Open face helmet } \\
\text { - Noise standards } \\
\text { - }\end{array}$ & $\begin{array}{l}\text {-Average noise } 93.6 \mathrm{dBA} \text {, lowest } 87.2 \mathrm{dBA} \text {, highest } 106.9 \mathrm{dBA} \\
\text { (OSHA-HC) } \\
\text {-Average noise } 92.5 \mathrm{dBA} \text {, lowest } 83.6 \mathrm{dBA} \text {, highest } 106.8 \mathrm{dBA} \\
\quad \text { (OSHA-PEL) } \\
\text {-Average noise } 95.29 \mathrm{dBA} \text {, lowest } 88.8 \mathrm{dBA} \text {, highest } 109.8 \mathrm{dBA} \\
\quad \text { (ACHIG/NIOSH) }\end{array}$ \\
\hline
\end{tabular}

\subsection{Purpose of study}

The purpose of this study was to investigate the real-time motorcycling noise exposure experienced by young riders at various speeds, with motorcycle attributes and genders. This investigation is expected to compare motorcycling noise levels with previous studies, highlighting the lack of motorcycling noise standards and importance, and to determine noise levels at various speeds for gender differences and motorcycling attributes. 


\subsection{Objectives of the study}

In line with the purpose, the objectives of the study were to assess the at-ear noise exposure level of real-time motorcycling at designated speeds, to identify the differences in noise exposure levels based on Occupational Safety and Health AdministrationHearing Conversation (OSHA-HC), Occupational Safety and Health Administration-Permissible Emission Level (OSHA-PEL), and American Conference of Government Industrial Hygienists/ National Institute for Occupational Safety and Health (ACGIH/NIOSH) standards, and to determine the significant difference in the motorcycling attributes amongst gender.

\subsection{Methodology}

\subsection{Study site}

The test performance route was conducted on a closed-circuit study track (flat and asphalt two-lane straight road), with few road bumps and two roundabouts (Fig 1). The total distance was approximately $4,680 \mathrm{~m}(4.8 \mathrm{~km})$ with designated speed zones $(0-5)$. Description of speeds zone classification is, Zone 0 at $20 \mathrm{~km} / \mathrm{h}(200 \mathrm{~m})$, Zone 1 at $40 \mathrm{~km} / \mathrm{h}(100 \mathrm{~m})$, Zone 2 at $60 \mathrm{~km} / \mathrm{h}(1540 \mathrm{~m})$, Zone 3 at $80 \mathrm{~km} / \mathrm{h}(1560 \mathrm{~m})$, Zone 4 at $60 \mathrm{~km} / \mathrm{h}(800 \mathrm{~m})$, and Zone 5 at $40 \mathrm{~km} / \mathrm{h}(480 \mathrm{~m})$. Total traveling time based on distance per speed limits was approximately 7 minutes. Restricted to the low traffic flow and the availability of the participants, the test administration was usually conducted between 10:00 am - 01:00 pm.

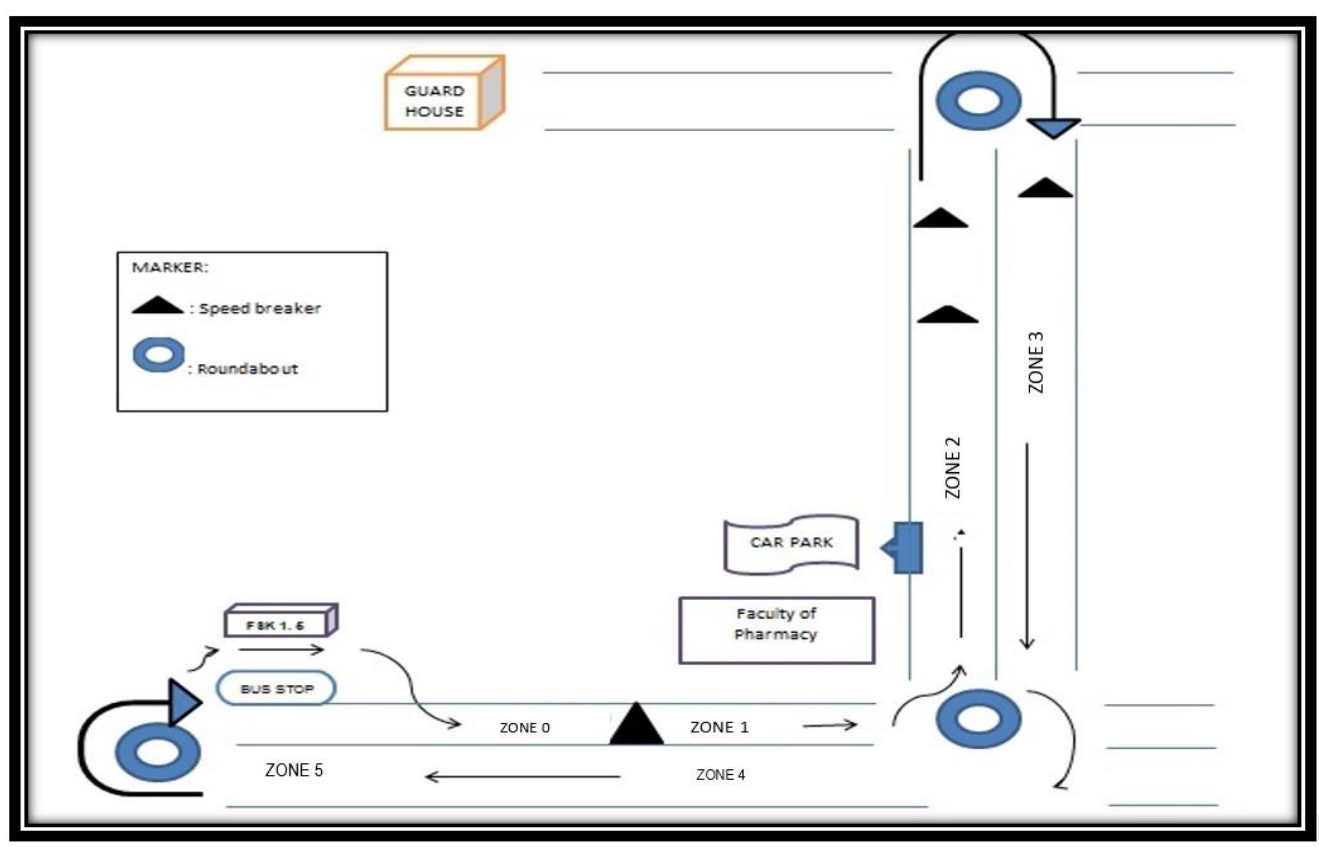

Figure 1: Study site and test performance route

\subsection{Instruments}

The structured questionnaire consisted of three segments; participants' demographic information (age, a semester of the study, and gender), motorcycling data (license number, motorcycle registration number, helmet type: full-face, modular, off-road, open-face, half, dual-sport), the motorcycle brand (Yamaha, Honda, NIMOTA, Modenas), engine capacity (ranging: 100-150 cc) and previous road accidents, weather conditions (dry, rain, fog, haze), and starting, ending time, date and traffic flow (high, medium, low) of test-ride.

Rider's at-ear noise exposure level was measured using a pocket-size dosimeter (3M Noise ProTM, model: Noisepro DLX, Sound Pro Quest). Pre and post calibrations were conducted before and after each monitoring session through a sound level calibrator (QUEST). Table 1 presents the three dosimeter integrator configuration settings of logging interval, time-weighted and criterion time. The first and second virtual dosimeters configurations were based on the Occupational Safety and Health Administration (OSHA) criterion (Gilbertson \& Vosburgh, 2015). The first virtual dosimeter was programmed to noise threshold of $80 \mathrm{dBA}$, criterion level of 90 $\mathrm{dBA}$, and exchange rate $5 \mathrm{~dB}(\mathrm{OSHA}-\mathrm{HC})$. The second virtual dosimeter was programmed without noise threshold, criterion level 90 $\mathrm{dBA}$, and exchange rate $5 \mathrm{~dB}$, (OSHA -PEL). The third virtual dosimeter was configured at $80 \mathrm{~dB}$ threshold, $85 \mathrm{dBA}$ criterion level, and the exchange rate of $3 \mathrm{~dB}$ American Conference of Government Industrial Hygienists/ National Institute for Occupational Safety and Health (ACGIH/NIOSH). Participants used their motorcycle, which varied in brands and engine capacities. All motorcycles used had no windshield attached while all the riders wore open-faced helmets with a closed visor. Fuel consumption and participation were compensated with vouchers and incentives. 
Table 2. Dosimeter Integrator Configurations based on OSHA-HC, OSHA-PEL, ACGIH/NIOSH

\begin{tabular}{lccc}
\hline Integrators & OSHA-HC & OSHA-PEL & ACGIH/NIOSH \\
\hline Exchange Rate (dB) & 5 & 5 & 3 \\
Time Weighting & Slow & Slow & Slow \\
Frequency Weighting & $\mathrm{dB}(\mathrm{A})$ & $\mathrm{dB}(\mathrm{A})$ & $\mathrm{dB}(\mathrm{A})$ \\
Threshold (dB) & 80 & 90 & 80 \\
Criterion Time (hrs) & 8 & 8 & 8 \\
Criterion Level (dB) & 90 & 90 & 85 \\
\hline
\end{tabular}

\subsection{Test-track performance}

The track performance consisted of the helmet at-ear noise assessment of motorcycle riders at various speed restrictions in a closedcircuit track. The study protocol included participant's arrival with their motorcycle and helmet at the designated testing site (FSK, 1.5, UiTM, Faculty of Health Sciences). Upon arrival, participants' demographic data were recorded followed by dosimeter installation upon them. The procedure for dosimeter installation was as follows; the calibrated dosimeter (114 dBA) attached with a small microphone (Type 2) was placed near the entrance of the ear canal, so as not to be in contact with any other parts of the ear. To prevent unnecessary movements of the microphone, it was attached with clips inside the helmet. The microphone was attached to the dosimeter with a thin microphone cord and a cord was drawn at the front of the participant and clipped firmly onto the clothing. The dosimeter itself was placed inside the front basket of the motorcycle and covered with a front cover, for dosimeter safety. The participant's helmet was fixed and buckled tightly to avoid displacement of wires and the microphone. The start and end of the testride were at Zone 0 . Upon their return, dosimeter data was saved and uninstalled from the participants. All test measurements were carried out in dry weather conditions and during the lowest traffic flow. Later, raw data from each test dosimeter was transferred to computer software (3M Detection Management Software, DMS, USA), which generated a detailed report of each noise assessment session. Data encoded were started and stop time, device serial number, device model type, average A-weighted sound level (LAeq), and TWA (time-weighted average).

\subsection{Data Analysis}

Participants' information and dosimeter data were tabulated and logged on an Excel worksheet for database and computed for statistical analysis through Statistical Package for Social Sciences, IBM SPSS (Version 22 Inc., Chicago, IL). Data at various speeds were computed through a dosimeter logged data table which provides detailed noise exposure levels for each minute. Below $60 \mathrm{dBA}$, (below a threshold level) the decibel levels are replaced with a value of $0 \mathrm{dBA}$. Therefore, at the end of each zone (speed breakers and roundabouts) the value is stated as 0 .

Data distribution was also tested through the Shapiro-Wilk test of normality for the 40,60 and $80 \mathrm{~km} / \mathrm{h}$ test performance starts and return and was statistically normally distributed $(p<0.05)$. The average noise level exposure (LAeq), engine capacity usage, and duration of ride completion differences between genders were computed through the independent $t$-test. The difference in the LAeq among zones was computed through a paired sample $t$-test. The relation between LAeq and duration of ride completion and engine capacity (Class 1: 100-115cc; Class 2: 125-150cc) was evaluated through the independent $t$-test. Bar charts were also plotted to demonstrate the differences among LAeq exposures at various speeds $(40,60$, and $80 \mathrm{~km} / \mathrm{h})$ test performance at the start and return.

\subsection{Findings}

\subsection{Demographic Profile of the Participants}

Table 3 presents the demographic profile of the recruited participants $(n=26)$. Participation was dominated by males at $(73.1 \%)$. Participants' mean age was 22.92 .79 (ranged: 21 to 25 yrs). Motorcycle brands varied among which $53.8 \%$ owned Yamaha, while $19.2 \%, 15.4 \%$, and $11.5 \%$ rode Honda, Modenas, and NIMOTA brands, respectively. Motorcycle engine capacities varied between $100-150 \mathrm{cc}$, among which $34.6 \%$ rode a motorcycle with an engine capacity of $110 \mathrm{cc}$. However, $23.1 \%, 15.4 \% .11 .5 \%, 11.5 \%$, and $3.8 \%$ rode a motorcycle with an engine capacity of $135 \mathrm{cc}, 125 \mathrm{cc}, 115 \mathrm{cc}, 150 \mathrm{cc}$ and $100 \mathrm{cc}$, respectively. The average duration of test performance ride undertook was $465 \pm 39.4$ seconds, ranging between 396 to 534 seconds. All participants have licensed motorcyclists and possessed registered vehicles with a history of minor or no motorcycle accidents.

\subsection{Motorcycle Noise Assessment on Different Noise Standards}

Table 4 presents the descriptive results of the three virtual dosimeters based on the three noise standard integrators. The LAeq for OSHA-HC was $85 \pm 3.6 \mathrm{dBA}$, ranging from 78 to $91 \mathrm{dBA}$. OSHA-PEL showed LAeq of $91 \pm 7.8 \mathrm{dBA}$, ranging from $61.4-78 \mathrm{dBA}$. LAeq for ACGIH/NIOSH was $87 \pm 3.45 \mathrm{dBA}$, ranging from 81.3 to $94.5 \mathrm{dBA}$. The 8-hour TWA normalized noise exposures for OSHA$\mathrm{HC}$, OSHA-PEL and ACGIH/NIOSH average were $55 \pm 3.55 \mathrm{dBA}$ (ranging:81 - 95), $47 \pm 11.82 \mathrm{dBA}$ (ranging: $49-62$ ), $69 \pm 3.1 \mathrm{dBA}$ (ranging: $32-58$ ) respectively. Fig 2 illustrates the comparisons of LAeq of the participants based on (A) OSHA-HC, (B)OSHA-PEL, and (C) ACGIH/NIOSH standards. 
Table 3. Demographic profile of participants

\begin{tabular}{|c|c|c|c|c|c|}
\hline \multirow{2}{*}{$\begin{array}{l}\text { Variables } \\
\text { Gender }\end{array}$} & & $\mathrm{N}(\%)$ & Mean (SD) & Minimum & Maximum \\
\hline & & & $\begin{array}{l}\text { Male: } 19(73.1) \\
\text { Female: } 7(26.9)\end{array}$ & & \\
\hline Age (years) & $\begin{array}{l}21 \\
22 \\
23 \\
24 \\
25\end{array}$ & $\begin{array}{c}2(7.7) \\
2(7.7) \\
19(73.1) \\
2(7.7) \\
1(3.8)\end{array}$ & $22.92(0.79)$ & 21 & 25 \\
\hline Brand & $\begin{array}{r}\text { Yamaha } \\
\text { Honda } \\
\text { Modenas } \\
\text { NIMOTA }\end{array}$ & $\begin{array}{c}14(53.8) \\
5(19.2) \\
4(15.4) \\
3(11.5)\end{array}$ & $1.8(1.1)$ & 1 & 4 \\
\hline $\begin{array}{l}\text { Engine Capacity } \\
\text { (cc) }\end{array}$ & $\begin{array}{l}100 \\
110 \\
115 \\
125 \\
135 \\
150\end{array}$ & $\begin{array}{c}1(3.8) \\
9(34.6) \\
3(11.5) \\
4(15.4) \\
6(23.1) \\
3(11.5)\end{array}$ & $122.8(14.5)$ & 100 & 150 \\
\hline $\begin{array}{l}\text { Duration of ride traveled } \\
\text { (seconds) }\end{array}$ & & & $465(39.4)$ & 396 & 534 \\
\hline
\end{tabular}

Table 4. Descriptive analysis of Average Noise Exposure (LAeq, dBA) based on OSHA-HC, OSHA-PEL, ACGIH/NIOSH

\begin{tabular}{llll}
\cline { 1 - 3 } Dosimeter Configuration & Mean (dBA) & SD & Range (dBA) \\
\hline Lavg OSHA-HC & 85 & 3.6 & $78-91$ \\
Lavg OSHA-PEL & 78 & 7.8 & $61-91$ \\
Lavg-ACGIH/NIOSH & 87 & 3.45 & $81-94$ \\
\hline & 8-hr TWA Normalized noise exposure & \\
\cline { 1 - 3 } OSHA-HC & 55 & 3.55 & $81.3-94.5$ \\
OSHA-PEL & 47 & 11.82 & $49.3-61.7$ \\
ACGHH & 69 & 3.1 & $31.8-58$ \\
\hline
\end{tabular}

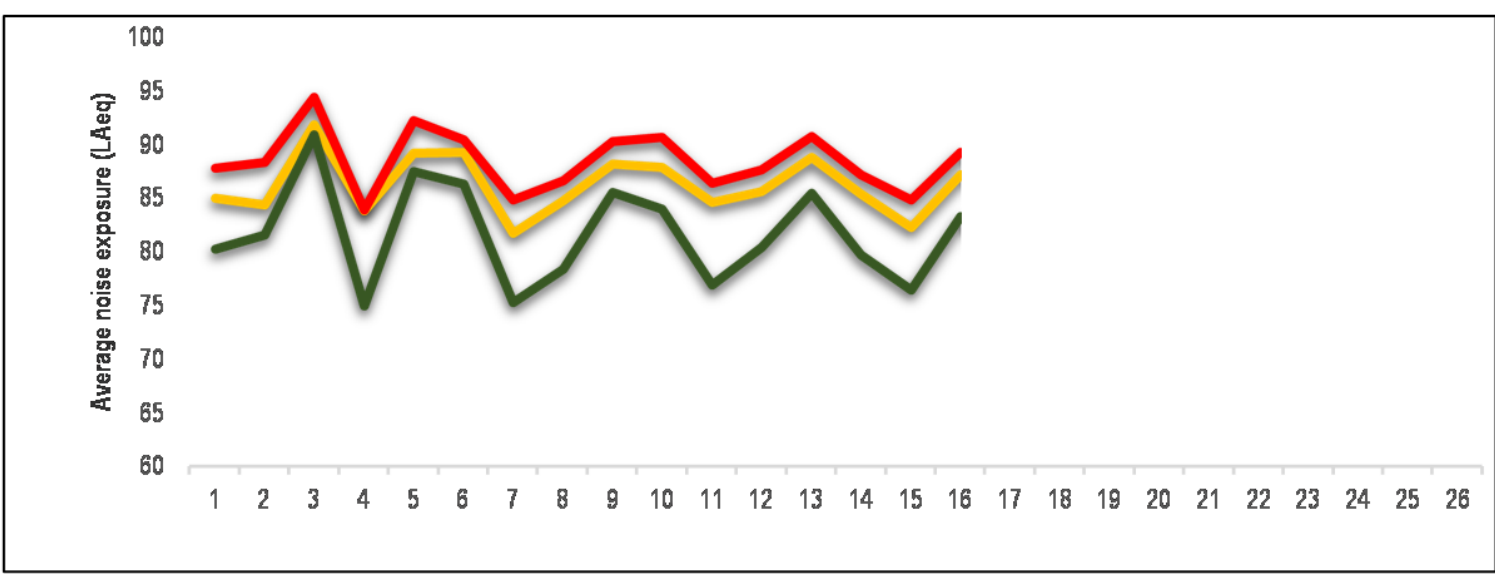

Fig 2: Comparisons of average noise level (LAeq) exposure of participants based on (---) OSHA-HC, (---) OSHA-PEL, and (---) ACGIH/NIOSH

\subsection{Gender differences}

Gender differences to average noise exposure, motorcycle engine capacity (cc) usage, and duration of ride completion were also computed. Results showed (Fig $3 A$ ) a significant difference $[t(2.35)=24, p=.027$ ] in the LAeq amongst males, $(85.9 \pm 3.07 \mathrm{dBA})$ compared to females $(82.5 \pm 4.04 \mathrm{dBA})$ indicating males as being exposed to higher noise levels. Further, a significant difference $[\mathrm{t}(2.110)=24, p=0.045]$ was found between male $(126.3 \pm 15.4 \mathrm{cc})$, and female $(113.57 \pm 5.5 \mathrm{cc})$ riders to motorcycling engine capacity (cc) usage (Fig $3 \mathrm{~B}$ ) indicating that female riders tend to ride the motorcycle engines with lower capacity. However, no significant difference $[\mathrm{t}(-1.686)=24, p=0.105]$ was found between male $(458.11 \pm 39.39$ seconds) and female $(486.43 \pm 33.451$ seconds) riders on the completion time (Fig $3 \mathrm{C}$ ) of the test-ride. 


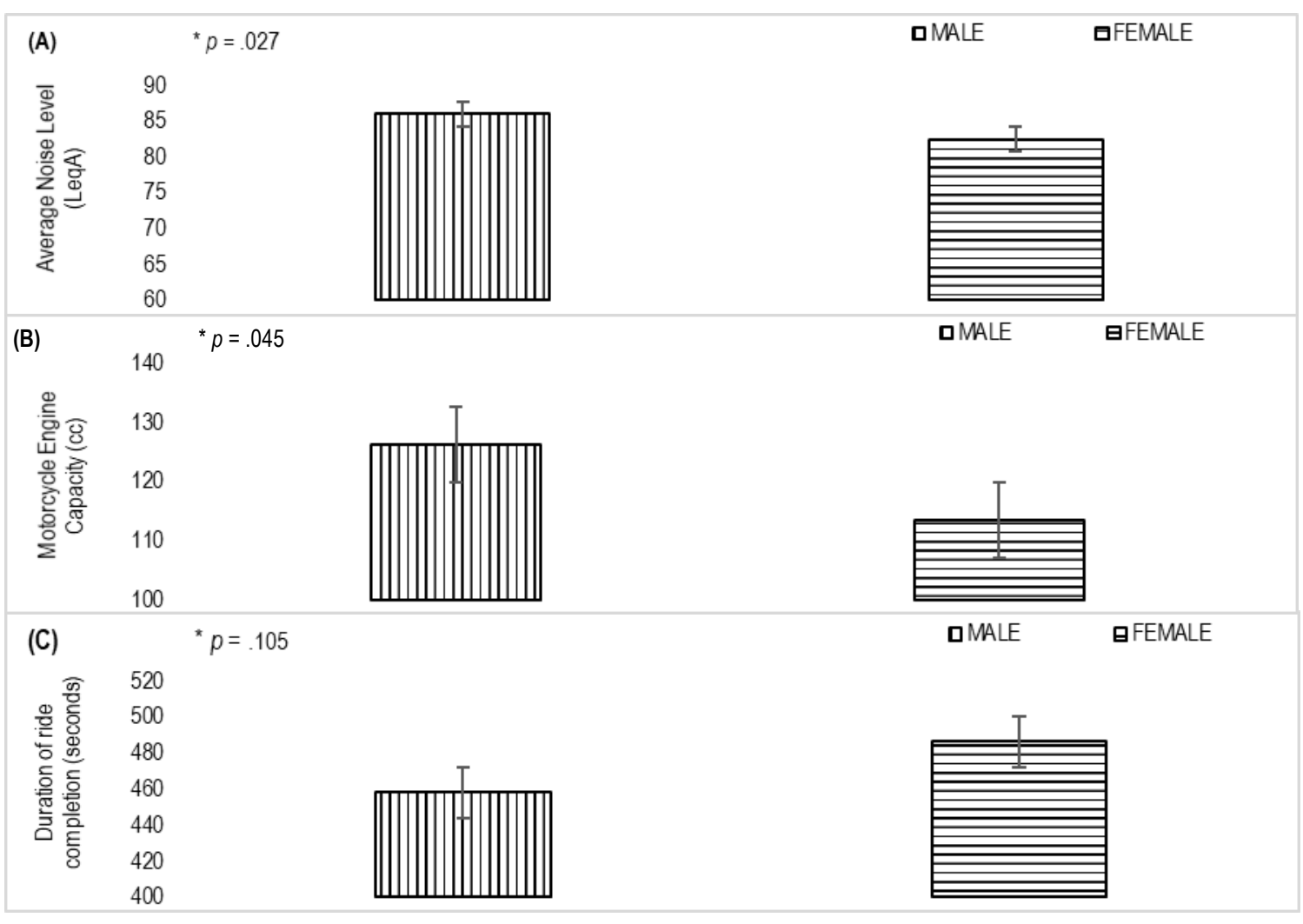

Fig 3: Gender differences based on (A) average noise exposure (LAeq, dBA); (B) motorcycle engine capacity (cc); (C) duration of ride completion (seconds)

\subsection{Noise Exposure at Various Speeds}

Table 5 presents the LAeq at different zones within the test performance route at designated speeds. Results showed LAeq at Zone 1 (start: $40 \mathrm{~km} / \mathrm{h}$ ), Zone 2 (start: $60 \mathrm{~km} / \mathrm{h}$ ), Zone 3 (midway: $80 \mathrm{~km} / \mathrm{h}$ ), Zone 4 (return: $60 \mathrm{~km} / \mathrm{h}$ ), Zone 5 (return: $40 \mathrm{~km} / \mathrm{h}$ ) of $71.64 \pm 4.36$ dBA (60.63-78.58 dBA), 83.36 $\pm 3.25 \mathrm{dBA}(76.75-88.7 \mathrm{dBA}), 88.46 \pm 2.02 \mathrm{dBA}(84-92 \mathrm{dBA}), 81.39 \pm 3.23 \mathrm{dBA}(74.1-86.9 \mathrm{dBA})$ $76.74 \pm 4.2 \mathrm{dBA}(63.64-83.64 \mathrm{dBA})$, respectively. A signficant difference $[t(-11.863)=25, p=.000]$ in the LAeq was determined between Zone 1 and Zone 2, as well as between: Zone 2 and Zone $3[t(-8.938)=25, p=.000]$, Zone 3 and Zone 4 [t(10.550)=25, $p=.000]$, Zone 4 and Zone 5, $[t(4.610)=25, p=.000]$. Figure 4 shows the comparison of LAeq at different zones which indicates that travelling at $80 \mathrm{~km} / \mathrm{h}$ had the highest LAeq exposure ( $88 \mathrm{dBA})$, while travelling at $40 \mathrm{~km} / \mathrm{h}$ and $60 \mathrm{~km} / \mathrm{h}$ both ways constituted LAeq of 74 and $82 \mathrm{dBA}$, respectively.

Table 5. Average noise exposure (LAeq, dBA) at designated zones ( speed limits)

\begin{tabular}{cccccc}
\multicolumn{7}{c}{ Table 5. Average noise exposure (LAeq, dBA) at designated zones (speed limits) } \\
\hline ZONES & Mean (dBA) & SD & $\begin{array}{c}\text { Minimum } \\
(\mathrm{dBA})\end{array}$ & $\begin{array}{c}\text { Maximum } \\
(\mathrm{dBA})\end{array}$ & P-value \\
\hline 1 & & 4.36 & 60.63 & 78.58 & .000 \\
2 & 71.64 & 3.25 & 76.75 & 88.7 & .000 \\
3 & 83.36 & 2.02 & 84 & 92 & .000 \\
4 & 88.46 & 3.23 & 74.1 & 86.9 & .000 \\
5 & 81.39 & 4.2 & 63.64 & 83.58 & .000 \\
\hline
\end{tabular}

Note: * $p$-value generated by paired sample t-test

\subsection{Assessment of Motorcycle Engine Capacity}

Table 6 shows the relationship between motorcycle engine capacity(cc) and LAeq. No significant differences [t $(-.748)=24, p=.462]$ were found between motorcycle engine capacities of 100-115cc (84.5 $\pm 4.3 \mathrm{dBA})$ and 125-150cc (85.58 $\pm 2.8 \mathrm{dBA})$ with LAeq. Similarly, no significant differences $[t(-.397)=24, p=.695]$ were found between completion of test performances ride (seconds) and motorcycle engine capacities of 100-15cc (462.62 $\pm 3.9 \mathrm{sec})$ and $125-150 \mathrm{cc}(468.85 \pm 40.5 \mathrm{sec})$. 


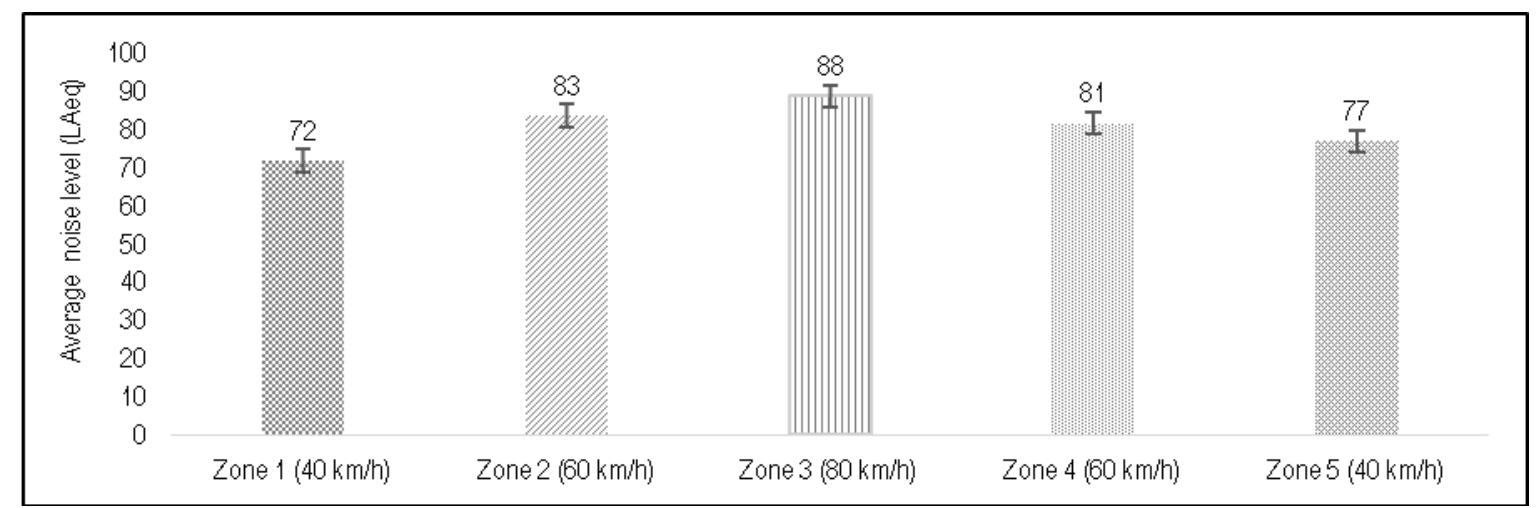

Figure 4: Comparison of average noise levels exposures (LAeq) at different speed $(\mathrm{km} / \mathrm{h})$ zones in a closed-circuit test performance track

Table 6: Motorcycle engine capacity (cc) association with average noise level exposure (LAeq) and completion of the ride (Seconds)

\begin{tabular}{cccc}
\hline Variables & \multicolumn{2}{c}{ Motorcycle Engine Capacity } & \\
& $100-115 \mathrm{cc}$ & $125-150 \mathrm{cc}$ & \\
\cline { 2 - 3 } & $(n=13)$ & $(n=13)$ & \\
& $\mathrm{M} \pm \mathrm{SD}$ & $\mathrm{M} \pm \mathrm{SD}$ & \\
\hline Average noise exposure $(\mathrm{LAeq})$ & $84.5 \pm 43$ & $85.6 \pm 2.8$ & .462 \\
Completion of ride $(\mathrm{Sec})$ & $462.6 \pm 3.9$ & $468.8 \pm 40.5$ & .695 \\
\hline
\end{tabular}

\subsection{Discussion}

\subsection{Motorcycle Noise Assessment on Different Noise Standards}

In this study, comparisons of average noise level (LAeq) of the participants in terms of the sound pressure were the same for all the three integrators based on Occupational Safety and Health Administration-Hearing Conversation (OSHA-HC), Occupational Safety and Health Administration-Permissible Emission Level (OSHA-PEL), and American Conference of Government Industrial Hygienists/ National Institute for Occupational Safety and Health $(\mathrm{ACGIH} / \mathrm{NIOSH})$ standards but the differences between them demonstrates substantially different results because of variances in the configuration of the integrators. Such differences are attributed to the effects of the opposing threshold levels, exchange rates, and criterion levels, which combine to provide significantly different results. In this study the lowest level recorded LAeq of participants was $78 \mathrm{dBA}$ (OSHA-PEL) and the highest level was $87 \mathrm{dBA}(\mathrm{ACGIH/NIOSH})$. Neither of these measurements is incorrect or erroneous but are merely the result of the usage of occupational noise standards whose origins as well as configurations are very dissimilar. However, the differences emphasize the need and importance of establishing common and standardized measuring protocols for assessing motorcycle noise exposure levels (A Ali et al., 2018).

According to Table 4, the maximum recorded 8-hourly average sound level (TWA) for the distance of $4.8 \mathrm{~km} / \mathrm{h}$ at-ear of the motorcyclists was $69 \mathrm{dBA}$ (ACGIH/NIOSH), which is within the permissible noise level ( $85 \mathrm{dBA})$ and does not represent a hazardous level for the young riders at the maximum riding speed of $80 \mathrm{~km} / \mathrm{h}$ (Occupational Noise Exposure, Code of Federal Regulations Title 29, Part 1910.95 Subpart G, n.d.)

\subsection{Gender Differences}

This is the first study that investigated the gender differences (Fig 3) to average noise exposure level, motorcycle engine capacity (cc) usage, and completion of test ride (s). Binnington et al., 1993 reported that motorcycle noise exposure was not constant among riders. Similarly, Fig $3 \mathrm{~A}$ indicated male participants as being exposed to significantly higher noise levels $(p=.027)$ as compared to female participants, while Fig 3B demonstrated that the female participants use motorcycles with lower engine capacities $(p=.045)$. However, no significant difference $(p=.105)$ amongst genders was found for the completion of the test-track ride, but the mean difference of the completion of the ride (Fig $3 \mathrm{C}$ ) was higher among female than the male riders. This study constituted a larger sample size which may reflect the different styles of riding, as according to Carley et al., 2011a, varying riding position has a different impact of noise on riders' ears. Full upright and half-forward riding positions result in a change of $10 \mathrm{~dB}$ at-ear noise level exposure (Kennedy et al., 2013). This study revealed that usage of lower engine capacity motorcycles plus riding with speed compliance by female riders led to lower noise exposure and longer riding duration (safe riding). Results highlighted the important findings of the usage of a lower capacity motorcycle engine and riding at a speed up to $80 \mathrm{~km} / \mathrm{h}$ which has reduced impact on higher noise exposure which inversely would reduce the deteriorating impact on rider's psychophysiological health and overall quality of life health. It also emphasizes the importance of considering the gender differences while conducting motorcycle noise assessments.

\subsection{Noise Exposure at Various Speeds}

Daily exposures of the noise level that motorcyclists experience may typically exceed $90 \mathrm{dBA}$. Harvey et al., 2002 stated that at all motorcycle speeds, noise levels exceed $90 \mathrm{dBA}$, while results of this study showed that the LAeq simultaneously on all three virtual dosimeters under the open-faced helmet at 40,60 and $80 \mathrm{~km} / \mathrm{h}$ was below $90 \mathrm{dBA}$ (Table 5). The lowest recorded noise was $72 \mathrm{dBA}$ at $40 \mathrm{~km} / \mathrm{h}$ while the highest was $88 \mathrm{dBA}$ at $80 \mathrm{~km} / \mathrm{h}$ (Fig 4). Jordon 2000 reported the lowest motorcycle LAeq of $83.66 \mathrm{dBA}$ and 
highest $109.4 \mathrm{dBA}$ from Sound Level Meter. In this study, the LAeq at $40 \mathrm{~km} / \mathrm{h}$ was $74 \mathrm{dBA}$ which was following with the study by Lower et al., 1996, (70-80 dBA at $48 \mathrm{~km} / \mathrm{h})$, while in contradiction with Ross,1999 (95 dBA at $48 \mathrm{~km} / \mathrm{h}$ ), Jordan et al., 2000 (87.2 dBA at $50 \mathrm{~km} / \mathrm{h}$ ) and Violini et al., $2016(105.7 \mathrm{dBA}$ at $40 \mathrm{~km} / \mathrm{h})$. According to Harvey et al, 2002 there is an increase of noise up to $4 \mathrm{dBA}$ with an increase of every $10 \mathrm{~km} / \mathrm{h}$ in speed.

Cross analysis of the results with previous studies is challenging due to the absence of noise standards and variability among instrumentation and methods in assessing noise levels. The acoustic environment to the riders may vary from one another based on multiple variables (Binnington et al., 1993). Ross, 1989b stated that open-faced helmets as less noisy, with a difference of $7 \mathrm{dBA}$, compared to close-faced helmets. Participants in this study are expected to experience higher noise levels if closed-faced helmets were used. Carley et al., 2011a and John Kennedy, Holt, et al., 2011), reported a significant interaction of helmet with windscreen angle and location on sound pressure level and noise spectral content, with a difference of $10 \mathrm{~dB}$ (more aerodynamic effect). The edge and fairing of the windscreen are also highly turbulent (Lower et al., 1996; Jordan et al., 2004), while vortex shielding generates noise flow from motorcycle windscreen (Carley et al., 2011). However, no windscreens were attached to motorcycles used in this study. Wet roads also tend to generate higher noise levels (5-4 dB) than dry roads (Ross, 1989b; Harvey et al., 2002). Hypothetically it can be presumed that under wet weather conditions noise exposure levels would be greater than dry weather.

\subsection{Assessment of motorcycle engine capacity}

Table 5 states no significant effect of motorcycle engine capacity on LAeq $(p=.462)$ and completion of test performance ride $(p=.695)$. Results from this study evident that motorcycle engine capacity does not affect generating noise levels, while wind noise dominates with the function of the speed (Moorhem et al., 1981; Jordan 2000) and it changes both in character and volume (Binnington et al., 1993; Carley et al., 2011). Results suggest that motorcycle engine capacity has merely no impact on generating higher noise levels, therefore motorcyclists are advised for adjusting motorcycling behavior i.e., riding up to $80 \mathrm{~km} / \mathrm{h}$. Previous studies also stated that noise levels predominate only with increasing speed (aerodynamic effect), therefore, lower speeds will lead to the reduced adverse impact of noise on its riders.

Thus, motorcyclists are exposed to continuous harmful exposure of noise while riding above $80 \mathrm{~km} / \mathrm{h}$, which may affect the overall quality of life, particularly of young riders (chronic exposure). This should be taken into account for health risk assessments related to injuries for future research through long-term longitudinal cohort studies (Anila Ali et al., 2016).

\subsection{Limitations of the Study}

The limitation of this study was the non-utilization of more instruments and devices such as aerometers and webcam digital recorder for assessing the wind speed outside the helmet and the riders riding position due to safety constraints of rider and instruments.

\subsection{Conclusion and Recommendations}

In conclusion, the results of the noise exposure levels in this study among motorcyclists were substantially different for OSHA-HC, OSHA-PEL, and ACGIH/NIOSH occupational noise standards with the highest recorded average noise level $87 \mathrm{dBA}, 69$ TWA for ACGIH/NIOSH. Female riders were inclined to use lower motorcycle capacities (cc) and rode at lower speeds, which resulted in lower noise exposure levels, in concurrence with longer ride durations. However, there was no observable association found between the average noise exposure levels with motorcycle engine capacity and overall completion of rides. It can be also concluded that noise exposure level functions with the increasing speed.

Future studies with larger sample sizes, equivalent gender ratios, multiple engine capacities, types of helmets along with long-term longitudinal cohort investigations are required to obtain the affected psychological and physiological health parameters of motorcyclists from prolonged motorcycling noise exposes. It can also be recommended considering the results found from this study that driving motorcycles at the speed of $80 \mathrm{~km} / \mathrm{h}$ should be implemented by the Law Enforcement Agencies for the safety of the riders for both as reducing accidents and health degradation. It is necessary for increasing the overall quality of life of the exposed population, especially among young adult motorcycle riders.

\section{Acknowledgment}

We are very grateful to the Faculty of Health Sciences, Universiti Teknologi MARA, for providing instruments for data collection. We are also highly thankful to Dr. Subramaniam (Ex-HoD, Dept Environmental Health, and Safety) for his constant support, guidance, and insightfulness in this project. We are also grateful for participants and undergraduate research assistants David Judd Marcus and Farhana Ramli for assisting data collection and organizing participants at the study site.

\section{References}

Ali, A, Hussain, R. M., Abdullah, M., \& Dom, N. C. (2018). At-Ear Noise Levels Under the Helmet: A Field Study on Noise Exposure of Young Motorcyclists. Journal of Fundamental and Applied Sciences, 10(3S), 218-231. 
Ali, Anila, Dom, N. C., Hussain, R. M., \& Abdullah, M. (2017). Effect of Motorcycling on Salivary Noise-Induced Cortisol among Young Motorcyclists. EnvironmentBehaviour Proceedings Journal, 2(6), 269-277.

Ali, Anila, Dom, N. C., Hussain, R. M., Karuppannan, S., \& Abdullah, M. (2018). Auditory Profile of Undergraduate University Motorcyclists : Prevalence of Hearing Loss and Hearing Impairment. EnvironmentAsia, 11(1), 217-229. https://doi.org/10.14456/ea.2018.16

Ali, Anila, \& Hussain, R. M. (2018a). A Controlled Study on Young Motorcyclist's Cognitive Function. Asian Journal of Behavioural Studies, 4(15), 10. https://doi.org/10.21834/ajbes.v4i15.168

Ali, Anila, \& Hussain, R. M. (2018b). Cognitive Impairment among Young Motorcyclists : A controlled study. Environment-Behaviour Proceedings Journal, 1-9.

Ali, Anila, Hussain, R. M., Abdullah, M., \& Dom, N. C. (2018). The effects of noise-sensitivity on young motorcyclist's salivary cortisol: A controlled experiment. Herald NAMSCA, 965-969.

Ali, Anila, Hussain, R. M., Dom, N. C., \& Abdullah, M. (2018). Noise-Induced Cortisol Assessment among Young Motorcyclist : A field study. Asian Journal of Quality of Life, 3(13), 117-127.

Ali, Anila, Hussain, R. M., Dom, N. C., \& Rashid, R. I. M. (2017). A Profile of Noise Sensitivity on the Health-Related Quality of Life Among Young Motorcyclists. Noise \& Health, 19(87), 112-113.

Ali, Anila, Karuppannan, S., Hussain, R. M., Rajan, S., Abdullah, M., Ikhwan, R., \& Chinna, K. (2016). Epidemiological root cause analysis of noise and physio - psycho impacts related to motorcycle road accidents. Journal of Scientific Research and Development, 3(5), 150-156.

Binnington, J. D., Mccombe, A. W., \& Harris, M. (1993). Warning signal detection and the acoustic environment of the motorcyclist. British Journal of Audiology, 27(6), 415-422.

Brown, C. H., \& Gordon, M. S. (2011). Motorcycle helmet noise and active noise reduction. The Open Acoustics Journal, 4, 14-24.

Carley, M., Holt, N., \& Walker, I. (2010). Noise mechanisms in motorcycle helmet noise. Proceedings of Meetings on Acoustics, 9(040005).

Carley, M., Kennedy, J., Walker, I., \& Holt, N. (2011a). The experimental measurement of motorcycle noise. Proceedings of Meetings on Acoustics, $12(5), 040002$.

Carley, M., Kennedy, J., Walker, I., \& Holt, N. (2011b). The experimental measurement of motorcycle noise. In Proceedings of Meetings on Acoustics, 12 (1), 040002.

Carriho, J., \& Silva, M. da. (2012). Aerodynamic noise in motorcycle helmets. In II LAETA Young Researchers Meeting FEUP, Porto.

Chris Jordan, Oliver Hetherington, Alan Woodside, H. H. (2004). Noise-induced hearing loss in occupational motorcyclists. Journal of Environmental Health Research, $3(2), 70-77$.

García Violini, D., Sánchez-Peña, R. S., Velis, A., \& Posse, C. (2016). Active wind noise hybrid control in motorcycle helmets. Acoustical Science and Technology, $37(1), 21-29$.

Gilbertson, L. R., \& Vosburgh, D. J. H. (2015). Patrol Officer Daily Noise Exposure. Journal of Occupational and Environmental Hygiene, 12(10), 686-691.

Harvey, H. D., Hetherington, J. O., Woodside, A., \& Jordan, C. (2002). Noise induced hearing loss in motorcyclists. Association for European Transport.

Jordan, C., Hetherington, O., Woodside, A., \& Harvey, H. (2004). Noise induced hearing loss in occupational motorcyclists. Journal of Environmental Health Research, $3(2), 70-77$.

Kennedy, J., Adetifa, O., Carley, M., Holt, N., \& Walker, I. (2011). Aeroacoustic sources of motorcycle helmet noise. The Journal of the Acoustical Society of America, 130(3), 1164-1172.

Kennedy, J, Carley, M., Walker, I., \& Holt, N. (2013). On-road and wind-tunnel measurement of motorcycle helmet noise. Journal of the Acoustical Society of America, 134(3), pp 2004-2010.

Kennedy, J, Holt, N., Carley, M., \& Walker, I. (2014). The Influence of the acoustic properties of motorcycle helmets on temporary hearing Loss in motorcyclists. ACTA Acustica United with Acustica, 100(6), 1129-1138.

Kennedy, John, Carley, M., Holt, N., Walker, I., Engineering, M., \& Down, C. (2011). The effects of windscreen flow on noise in motorcycle helmets. In Proc. Mtgs. Acous, 12(1), 040005.

Kennedy, John, Holt, N., Carley, M., \& Walker, I. (2011). Spectral filtering characteristics of a motorcycle helmet. In Proceedings of Meetings on Acoustics, 12(1), 040001.

Loo, L. Y. Le, Corcoran, J., Mateo-Babiano, D., \& Zahnow, R. (2015). Transport mode choice in South East Asia: Investigating the relationship between transport users' perception and travel behaviour in Johor Bahru, Malaysia. Journal of Transport Geography, 46, 99-111.

Lower, M. C., Hurst, D. W., \& Thomas, a. (1996). Noise levels and noise reduction under motorcycle helmets. Proceedings of Internoise 96, 1, 979-982.

Occupational Noise Exposure, Code of Federal Regulations Title 29, Part 1910.95 subpart G. (n.d.). Retrieved March 25, 2015, from https://www.osha.gov/lawsregs/regulations/standardnumber/1910/1910.95

Ross, B. C. (1989a). Noise exposure of motorcyclists. Occupational Hygiene, 33, 123-127. 
Ali, A., et.al., AIVCE-BS-2, 2020ShahAlam, cE-Bs, FSPU, Universiti Teknologi MARA, Shah Alam, Malaysia, 02-03 Dec 2020, E-BPJ, 5(15), Dec 2020 (pp.425-435)

Ross, B. C. (1989b). Short communication: Noise exposure of motorcyclists. Annual Occupational Hygiene, 33(I), 123-127.

Van Moorhem WK, Shepherd KP, Magleby TD, T. G. (1981). The effects of motorcycle helmets on hearing and the detection of warning signals. Journal of Sound and Vibration, 77(1), 39-49.

Violini, D. G., Pena, R. S. S., \& Velis, A. (2015). Time-varying noise control in motorcycle helmets. Acoust. Sci \& Tech., 36(4), $333-335$. 